\title{
Safety inspection on level crossing JPL 727 km 537+453 Patak-Pathukan Road, Sleman, Yogyakarta
}

\author{
Dian Setiawan $\mathrm{M}^{1, *}$, Mayang Sari ${ }^{1}$, and Noor Mahmudah ${ }^{1}$ \\ ${ }^{1}$ Muhammadiyah University of Yogyakarta, Department of Civil Engineering, Yogyakarta, Indonesia
}

\begin{abstract}
Level crossing (LC) safety inspection between a highway and a railroad on Pirak-Pathukan Road, Sleman, Yogyakarta is necessary because this LC is located near various community centers, has high traffic volume, intersects with railway double tracks, and intersecting angle that is not perpendicular. This study aims to evaluate LC technical condition, analyse delay time and vehicles queue length, and evaluate pavement structure condition. The research results indicate: 1) LC technical conditions do not meet the requirements of Regulation of Director General of Land Transport No. 770 Year 2005; 2) The longest duration of LC gate closure occurred on Sunday at 15:05, that is 360 seconds, the highest traffic flow occurred on Monday (from the South side) that is equal to $1443 \mathrm{skr} /$ day, and the longest delay time occurs on Sunday at 15:05, that is 498 seconds; 3 ) The value of pavement condition index (PCI) is $82 \%$ very good.
\end{abstract}

\section{Introduction}

According to Undang-Undang No. 22 year 2009, Traffic safety is a circumstance to avoid a person from accident risk during traffic that can be caused by humans, vehicles, and/or environment. Trains become one of transportation modes that provides several benefits to the community because the travel cost is relatively cheap, can transport many people or goods related its capacity, efficient in time, safe and comfortable [1]. There are some factors that affecting accidents at highway and railroad crossings, which are vehicles, drivers, natural and weather conditions, signs and markings, level crossing geometric design, and road pavement conditions [2]. The safety inspection on a level crossing is a systematic examination of road and railway track on a level crossing to identify hazards, errors and deficiencies that can cause accidents. Inspection activities are usually conducted by PT. Kereta Api Indonesia or Ministry of Transportation.

The city of Yogyakarta has a number of level crossings, one of which is a level crossing that located at Pirak-Pathukan Road, Sleman, Yogyakarta. This level crossing is located in the area that close to various community activity centers, such as Gamping market, Gamping sub-district office, Godean sub-district office, PKU (Public Health Center) of Muhammadiyah Gamping, Tamantirto village hall, Mejing II Primary School, State Junior

* Corresponding author: diansetiawanm@ft.umy.ac.id 
High School 1 Kasihan, High School State 1 Godean, and Universitas Muhammadiyah Yogyakarta. In addition, this location is also adjacent to the national road of Wates Road in the South side and Godean Road in the North side. The purpose of this study is to inspect

the safety of level crossing in Pirak-Pathukan Road, Sleman, Yogyakarta on JPL 727 KM $537+453$. This study aims to evaluate technical condition of level crossing, analyse delay time and length of vehicles queue that occurring as the impact of level level crossing gateclosure, and to evaluate pavement structure condition using Pavement Condition Index (PCI) method. Secondary data in the form of train departure and arrival schedule information and list of level crossing in the Special Region of Yogyakarta obtained from PT. KAI DAOP VI Yogyakarta.understanding that surface run-off has to discharge immediately through drainage channel. If something occurs on the channel, it is the beginning of the continuous destruction of the road.

One solution offered is what people called as Sustainable Urban Drainage Systems (SUDS), i.e. a system which consists of one or more structures developed to manage surface water run-off [3]. The basic concept of this system is to improve water usefulness, to minimize the loss, and also to improve environmental conservation. One of the efforts is to detain or reduce the speed of the surface water run-off when rainfall and immediately infiltrate the water into soil. As a whole, SUDS can be categories into several rainfall retention facilities, as seen in Figure 1.

\section{Sustainable road drainage system concept}

\subsection{Level crossing}

Based on the Regulation of Director General of Land Transport No. 770 Year 2005 about technical guidelines for level crossing between road and railway track, the requirements for the construction of a level crossing includes [4]:

1) Road surface is not higher or lower than rail head $(0.5 \mathrm{~cm}$ tolerance).

2) There is a $60 \mathrm{~cm}$ long surface measured from outer side of rail track.

3) The maximum gradient for vehicle passing (calculated from the highest point on the rail head) is $2 \%$ measured from outer side of the flat surface and $10 \%$ for the next 10 meters.

4) The maximum width of level crossing for one line is 7 meters.

5) The angle of intersection between rail track and road is at least 90 degrees and the length of the straight road must be at least 150 meters from rail track.

6) Must be equipped with an opponent rail or other construction to ensure a groove for the train wheel.

7) Road segment that can be crossed between a road and a railroad has the following requirements: Class III, at least has 2 lanes and 2 directions, not on the curve, vertical alignment less than $5 \%$ from the rail track outer point, fulfill the visibility requirement, and in accordance with the General Plan of Spatial Planning (RUTR).

\subsection{Traffic flow}

Traffic flow (Q) is expressed in units of light vehicles (skr) per hour for one or more periods, for example during peak periods of morning, noon, or afternoon. Traffic flow is converted from vehicle per hour to skr per hour by using the equivalent value of light vehicles (ekr). The ekr values for each vehicle type are described in Table 1 below. 
Table 1 Value of light vehicle equivalent (EKR)

\begin{tabular}{|l|l|}
\hline Vehicle Type & EKR Value \\
\hline Light Vehicles (LV) & 1.0 \\
\hline Heavy vehicles (HV) & 1.3 \\
\hline Motorcycle (MC) & 0.4 \\
\hline
\end{tabular}

Source: Indonesian Road Capacity Guidance (PKJI) (2014)

$$
Q=Q_{L V} \times e k r_{L V}+Q_{H V} \times e k r_{H V}+Q_{M C} \times e k r_{M C}
$$

Where:

Q : Traffic flow (skr/jam)

QLV : Light vehicles flow

QHV: Heavy vehicles flow

QMC : Motorcycles flow

ekr : Equivalent value of light vehicles

\subsection{Delays}

According to the Indonesian Road Capacity Guidance [5], delay calculations include traffic delays and geometric delays. At a level crossing, the delay is affected by a stopped delay as a geometric delay and congestion delay as a traffic delay. Systematically can be expressed as follows:

$$
T=T_{L}+T_{G}
$$

Where:

$\begin{array}{ll}T_{L} & : \text { Traffic delay } \\ T_{G} & : \text { Geometric delay }\end{array}$

\subsection{Queue length}

According to the Indonesian Road Capacity, the queue length is a vehicle queuing along the level crossing approach and expressed in meters. The queue length starts to be measured when the level crossing gateis closed until the level crossing gateis opened.

\subsection{Pavement condition index ( $\mathrm{PCl}$ ) method}

According to Shahin [6], the assessment of pavement structures condition by Pavement Condotion Index (PCI) method is assessed based on the type of damage and the level of damage, and it can be used as a reference in maintenance efforts. Stages of calculation of pavement condition assessment as follows:

\section{Density}

Density is the percentage of damage to the total area of a type of damage to the area in a research unit measured in square meters or long meters. To calculate the value of density used the following formula:

Density $=\frac{A d}{A s} \times 100 \%$

or 
Density $=\frac{L d}{A s} \times 100 \%$

with:

Ad $=$ Total of damage area $\left(\mathrm{m}^{2}\right)$

$\mathrm{Ld}=$ Total of damage length $(\mathrm{m})$

As $=$ Total area of segment unit $\left(\mathrm{m}^{2}\right)$

\subsection{Deduct value}

Deduct Value is a reduction value for each type of damage obtained from the graph that shows density and deduct value relationship.

\subsection{Total deduct value (TDV)}

Total Deduct Value is the total of deduct value for each type of damage and level of damage in a segment unit.

\subsection{Corrected deduct value (CDV)}

Corrected Deduct Value obtained from the graph that shows relationship between TDV and CDV by choosing the suitable graph with number of Deduct Value that more than score 2.

\subsection{Pavement condition index ( $\mathrm{PCl})$}

Once the CDV is known, then the PCI value for each research unit or segment can be calculated by the following equation:

PCIs $=100-\mathrm{CDV}$

Where:

PCIs $=$ PCI for each segment unit

$\mathrm{CDV}=\mathrm{CDV}$ for each segment unit

\subsection{Rating}

The quality of pavement structures can be determined by inputting PCI values that have been calculated into PCI levels, i.e Failed (0-10\%), Very Poor (11-25\%), Poor 26-40\%), Fair (41-55\%), Good (56-70\%), Very Good (71-85\%), and Excellent (86-100\%) [6].

\section{Research stages}

This research was conducted at level crossing JPL 727 STA. $537+453$ in Pirak-Pathukan Road, Sleman, Yogyakarta (Figure 1). 


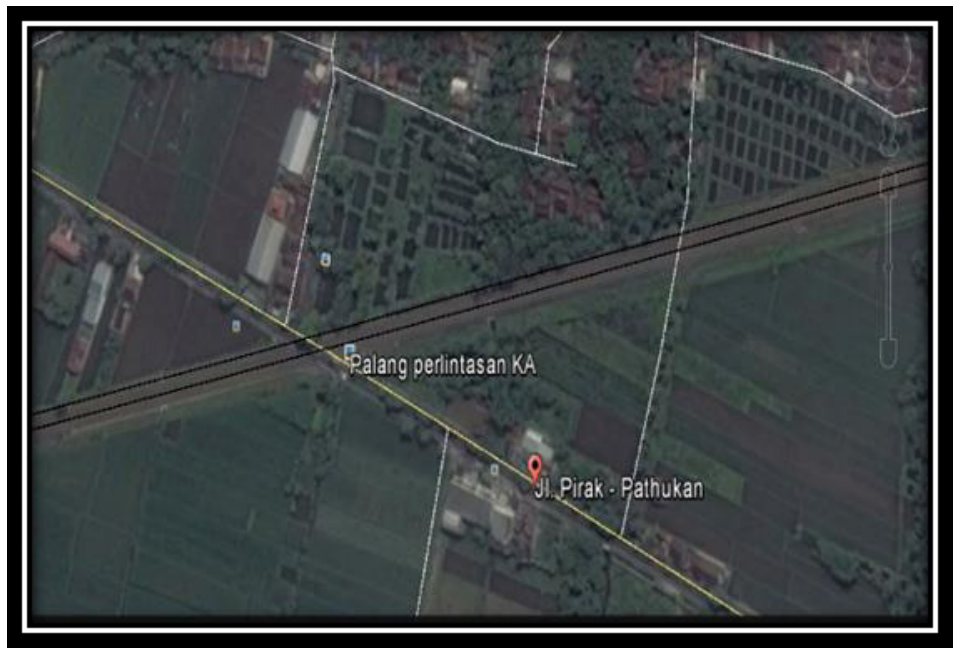

Fig. 1 Research sites

The primary data were obtained by conducting the following survey:

\subsection{Infrastructure condition}

The survey was conducted by direct observation along the segment of highway and railway line related to the signs, markings and traffic signal lights.

\subsection{Level crossing geometric}

The geometric survey was carried out by using the Garmin 76csx GPS tool to obtain the intersection angle of level crossing.

\subsection{Crossing door closure duration}

The survey was conducted to determine the time length of level crossing gateclosure.

\subsection{Vehicle time-delay}

The vehicle time-delay survey is conducted to obtain the time it takes for the vehicle to pass through a nuisance and obstacle at a level crossing.

\subsection{Vehicle queue length}

The queue length survey is intended to obtain the queue length that occurs at one time closure of the crossing gate.

\subsection{Pavement structure deterioration}

The survey of road pavement structural damage is done by direct observation along the highway under review. 


\subsection{Analysis of level crossing technical conditions}

A comparative stage between the parameters in the Regulation of Director General of Land Transport No. 770 Year 2005 about technical guidelines for level crossing between Road and Railway Track with the existing technical condition of level crossing on PirakPathukan Road, Sleman, Yogyakarta (JPL 727 KM $537+453)$ can be seen in Table 2 below.

Table 2. Result of technical condition analysis

\begin{tabular}{|c|c|c|c|}
\hline Parameters & $\begin{array}{l}\text { Technical Standards SK } \\
\text { Dirjen No. } 770(2005)\end{array}$ & Results in the Field & Information \\
\hline Train Schedule & Must fit Gapeka & Often late & $\begin{array}{l}\text { Does not meet } \\
\text { the requirement }\end{array}$ \\
\hline $\begin{array}{l}\text { Intermittent } \begin{array}{r}\text { time } \\
\text { between trains during } \\
\text { peak hour }\end{array} \\
\end{array}$ & Minimum 6 minutes & Less than 6 minutes & $\begin{array}{l}\text { Does not meet } \\
\text { the requirement }\end{array}$ \\
\hline $\begin{array}{l}\text { Number of passing } \\
\text { trains }\end{array}$ & $25-50$ trains/day & 89 trains/day & $\begin{array}{l}\text { Does not meet } \\
\text { the requirement }\end{array}$ \\
\hline Level crossing location & $\begin{array}{l}\text { Avoid curve in the } \\
\text { horizontal alignment }\end{array}$ & Not in curve & $\begin{array}{l}\text { Meet the } \\
\text { requirement }\end{array}$ \\
\hline Road class & Class III & Class III & $\begin{array}{ll}\text { Meet } & \text { the } \\
\text { requirement }\end{array}$ \\
\hline Rail track elevation & $\begin{array}{l}\text { Rail head and road surface } \\
\text { at the same height level }\end{array}$ & $\begin{array}{l}\text { Rail head\&road surface } \\
\text { has different height level }\end{array}$ & $\begin{array}{l}\text { Does not meet } \\
\text { the requirement }\end{array}$ \\
\hline Level crossing width & One line must be $\leq 7 \mathrm{~m}$ & One line $5 \mathrm{~m}$ & $\begin{array}{ll}\text { Meet } & \text { the } \\
\text { requirement }\end{array}$ \\
\hline $\begin{array}{l}\text { The angle of } \\
\text { intersection between } \\
\text { rail track \& highway }\end{array}$ & $90^{\circ}$ & $33^{0}$ & $\begin{array}{l}\text { Does not meet } \\
\text { the requirement }\end{array}$ \\
\hline $\begin{array}{lr}\begin{array}{l}\text { Distance } \\
\text { consecutive } \\
\text { crossings }\end{array} & \text { between } \\
\end{array}$ & $>800$ meter & 500 meter & $\begin{array}{l}\text { Does not meet } \\
\text { the requirement }\end{array}$ \\
\hline Average Daily Traffic & $300-500$ vehicles/day & 2956 vehicles/day & $\begin{array}{l}\text { Does not meet } \\
\text { the requirement }\end{array}$ \\
\hline Signs & $\begin{array}{l}\text { Must be equipped with } \\
\text { warning or prohibition } \\
\text { traffic signs }\end{array}$ & $\begin{array}{l}\text { There are no warning } \\
\text { signs No. } 23 \text { and } 24 \text { as } \\
\text { well as prohibition signs } \\
\text { No. } 5 \mathrm{c}\end{array}$ & $\begin{array}{l}\text { Does not meet } \\
\text { the requirement }\end{array}$ \\
\hline
\end{tabular}

Table 2. Result of Technical Condition Analysis (Continued)

\begin{tabular}{|l|l|l|l|}
\hline Parameters & $\begin{array}{l}\text { Technical Standards SK } \\
\text { Dirjen No. 770 (2005) }\end{array}$ & Results in the Field & Information \\
\hline Markings & $\begin{array}{l}\text { Must be equipped with } \\
\text { road markings }\end{array}$ & $\begin{array}{l}\text { No transverse and } \\
\text { symbol markers, rapping } \\
\text { ribbons, and medians }\end{array}$ & $\begin{array}{l}\text { Does not meet } \\
\text { the requirement }\end{array}$ \\
\hline Traffic light & $\begin{array}{l}\text { Two red lights flashing and } \\
\text { sound }\end{array}$ & $\begin{array}{l}\text { Two red lights flashing } \\
\text { and sound }\end{array}$ & $\begin{array}{l}\text { Meet requirement } \\
\text { req }\end{array}$ \\
\hline $\begin{array}{l}\text { Physical and non } \\
\text { physical facilities at } \\
\text { level crossings }\end{array}$ & $\begin{array}{l}\text { Guard posts, JPL officers, } \\
\text { semboyan lists, gapeka } \\
\text { lists }\end{array}$ & Everything is available & $\begin{array}{l}\text { Meet requirement } \\
\text { requan }\end{array}$ \\
\hline
\end{tabular}




\subsection{Impact analysis of level crossing closure}

The steps that required to obtaining delay duration and vehicle queue length due to the closure of level crossing gate are as follows:

\subsection{Closure duration}

A survey of level crossing gate closure duration is done to find variations of level crossing gate closure duration caused by the passing train. The data of level crossing gate closure duration for two days of observation are shown in Figure 2 below.

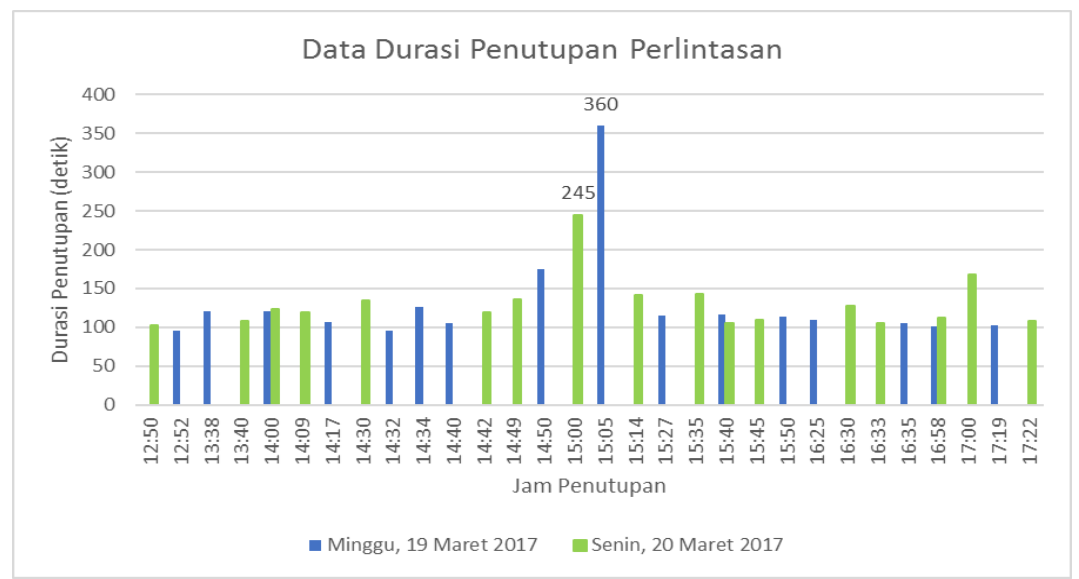

Fig. 2 Level crossing gate closure duration

\subsection{Traffic flow}

The data of traffic flow survey result at level crossing is shown in Figure 3.

\subsection{Delay Time and vehicle queue length}

The queue length varies on each approach lane of level crossing for each level crossing gate closure time. The data of delay time can be seen in Figure 4.

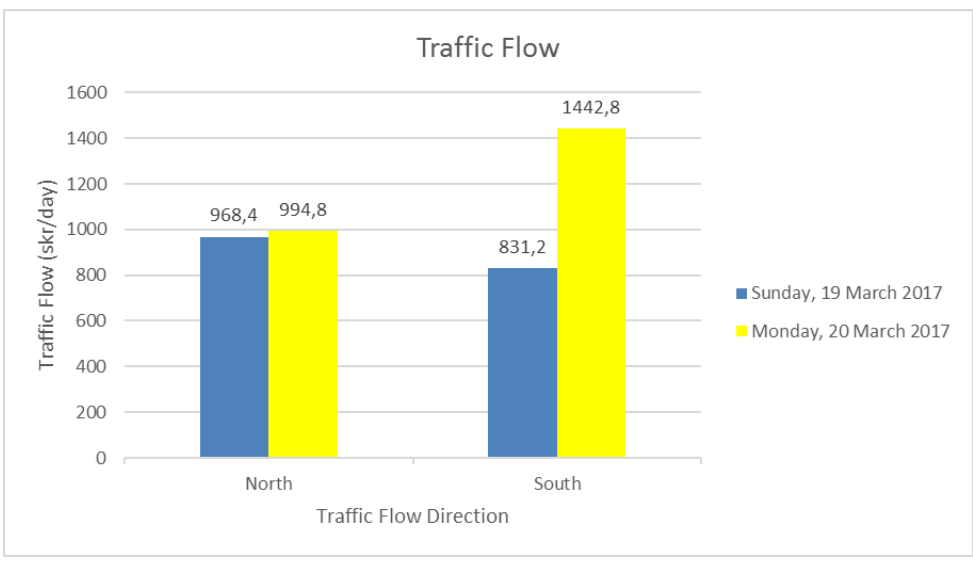

Fig. 3 Traffic flow 


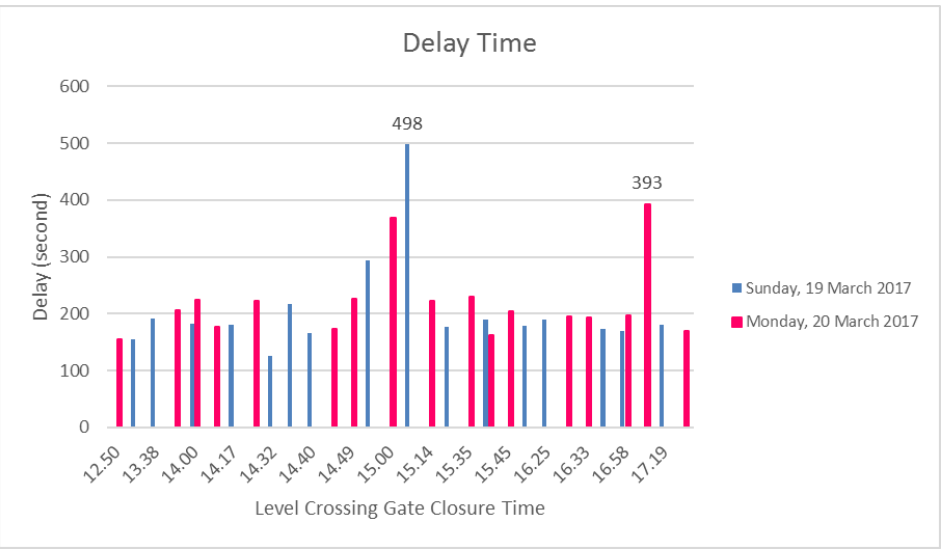

Fig. 4 Delay time

From the survey of delay time and vehicles queue length that conducted for 6 hours from 12:00 to 18:00 on Sunday, 19 March 2017, it can be obtained the result that the longest delay time occurred at 15:05 for 498 seconds. The delay time is influenced by the duration of the level crossing gate closure due to the passage of two trains at almost the same time, causing the vehicle queue length is 65 meters in the North side and 87 meters in the South side of level crossing. Furthermore, from the survey of delay time and vehicles queue length that conducted for 6 hours from 12:00 to 18:00 on Monday, 20 March 2017, it can be obtained the results that the longest delay time occurred at 17:00 for 393 seconds which is causing the vehicle queue length at that hour is 31 meters in the North side and 125 meters in the South side of level crossing.

\subsection{Analysis of pavement structure condition}

Table 3 PCI survey form

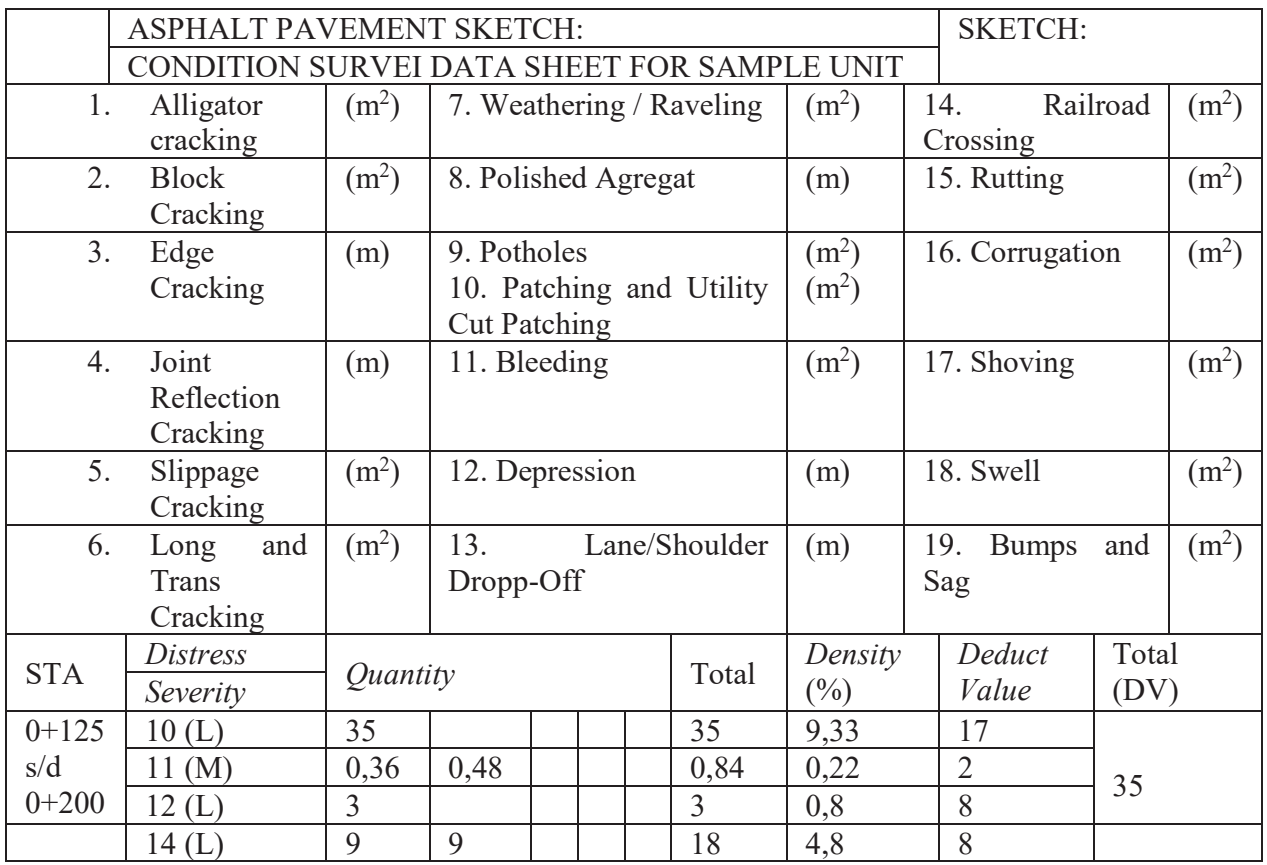


Based on a survey conducted on a road segment (200 meters to the North and 200 meters to the South) of level crossing JPL 727 STA. $537+453$, it was observed that there were road damages at STA. $0+125$ up to STA. $0+200$. This damage has been analysed using PCI method. The result of pavement condition analysis by PCI method can be seen in Table 3 .

Based on calculations, Total Deduct Value (TDV) is 35 with Q value is 3, resulting Corrected Deduct Value (CDV) is 18 from the CDV chart. Furthermore, the pavement condition value is obtained by subtracting 100 (one hundred) with the value of CDV that has been obtained. If the CDV value is known, then the PCI value of each segment unit can be calculated by the formula (5).

$$
P C I_{(S)}=100-C D V
$$

$$
=100-18=82
$$

From the PCI value of each segment unit, it can be concluded that the amount of PCI value of this road segment as in the following figure.

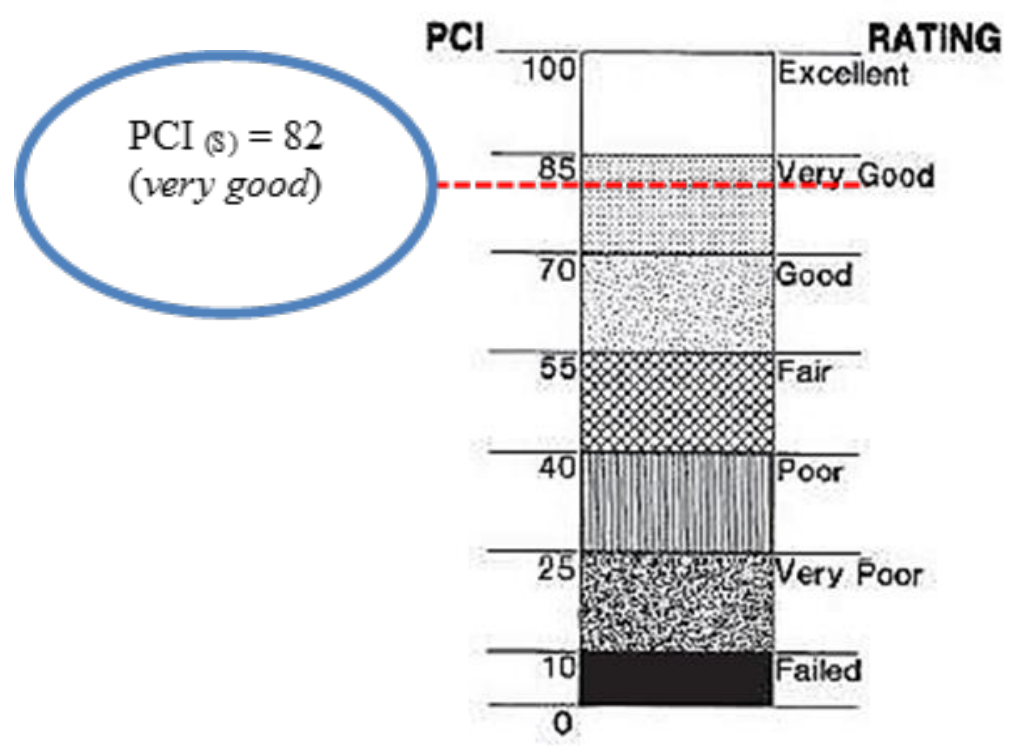

Fig. 5 PCI value chart

\section{Conclusion}

Based on the research that has been done, obtained the following conclusions:

1. The level crossing at Pirak-Pathukan Road, Sleman, Yogyakarta on JPL 727 KM $537+$ 453 according to the Regulation of Director General of Land Transport No. 770/2005 about technical guidelines for level crossing between road and railway track does not meet the requirements due to the passing train journey is often late, time intervals between trains during peak hours is less than six minutes, number of trains passing is more than 50 train/day, rail head and road pavement is in different elevation, distance between the consecutive level crossings is less than 800 meter, average daily traffic is 2956 vehicles /day, signs and markings are incomplete, and intersection angles between road and rail track is not perpendicular that could provide negative impact both for vehicle and train driver that passing this level crossing. 
2. Some parameters are analyzed as the impact of level crossing gate clossing, including as follows:

a. The longest closure duration of level crossing gate occurred on Sunday, March 19, 2017 at 15:05 for 360 seconds, while on Monday, March 20, 2017 occurred at 15:00 for 245 seconds.

b. The highest traffic flow that occurred on Sunday, March 19, 2017 comes from the North side that is equal to 1932 vehicles/day or equal to 969 skr/day. Furthermore, the highest traffic flow that occurred on Monday, March 20, 2017 comes from the South side that is equal to 2956 vehicles/day or equal to $1443 \mathrm{skr} /$ day.

c. The longest delay time on Sunday, March 19, 2016 occurred at 15:05 for 498 seconds with a queue length is 65 meters from the North side and 78 meters from the South side. Moreover, the longest delay time on Monday, March 20, 2017 occurred at 17:00 for 393 seconds with a queue length of 31 meters from the North Side and 125 meters from the South Side.

3. There are 4 types of damage on the road segment JPL $727 \mathrm{KM} 537+453$ along the 200 meters North-South direction, which are : patching $(9.33 \%)$, bleeding $(0.22 \%)$, depression $(0.8 \%)$, and railroad crossing $(4.8 \%)$. The value of the pavement conditions index (PCI) is $82 \%$ therefor it can be concluded that the road pavement is in very good condition.

\section{Reference}

1. Utomo, S.H.T. Jalan Rel. Beta Offset: Yogyakarta. (2013).

2. Hasan, B. Evaluasi Kelayakan Perlintasan Sebidang Studi Kasus Perlintasan Sebidang Patukan Gamping Sleman Yogyakarta. Tugas Akhir S-1 Jurusan Teknik Sipil, Fakultas Teknik UGM: Yogyakarta. (2009).

3. Estonia Latvia Programme, Handbook on Sustainable Urban Drainage Systems, European Union. (2013).

4. Direktorat Jenderal Perhubungan Darat. Pedoman Teknis Perlintasan Sebidang Antara Jalan Dengan Jalur Kereta Api. (2005)

5. Direktorat Jenderal Bina Marga. Pedoman Kapasitas Jalan Indonesia (PKJI). Departemen Pekerjaan Umum. Jakarta. (2014).

6. Hadiyatmo, H.C. Pemeliharaan Jalan Raya. Gadjah Mada University Press, Yogyakarta. (2007). 